\title{
A vasanyagcsere szabályozása, hepcidinexpresszió fiziológiás és pathológiás körülmények között
}

\author{
Egyed Miklós
}

Somogy Megyei Kaposi Mór Oktató Kórház, Hematológiai Osztály, Kaposvár

\begin{abstract}
A humán szervezetnek az alapvető biokémiai reakcióihoz vasra és annak biztonságos használatára van szükség. Emberben vasexcretios út hiányában a vasanyagcsere sarkalatos pontja a duodenális absorptio, amelyet a májsejtek által termelt hormon, a hepcidin szabályoz. A hepcidin a ferroportin lisosomalis degradációját okozva blokkolja a vasnak a vérbe való belépését a duodenális enterocytából, a reticuloendothelialis rendszer (RES) macrophagokból és a májsejtekből. A reguláló hormon képzését a szervezet vaskészlete mellett az erythropoiesis, hypoxia és inflammatorikus folyamatok befolyásolják. A szabályozás kóros eltérései vashiány vagy vasterhelés útján súlyos betegségeket okozhatnak. A hepcidin képződését befolyásoló folyamatokat illetően ismereteink jelentősen gyarapodtak, közleményünk célja ezek bemutatása.
\end{abstract}

Kulcsszavak: hepcidin, ferroportin

\section{Iron regulation, expression of hepcidin in physiologic and pathologic conditions}

The basic biochemical reactions of the human body require iron and its safe utilisation. In absence of an iron-excreation pathway in human, the pivotal point of iron metabolism is duodenal absorption, which is regulated by a hormone produced by liver cells, the hepcidin. Causing lisosomal degradation of ferroportin, hepcidin blocks the iron entry into the blood from duodenal enterocytes, reticuloendothelial system (RES) macrophages, and liver cells. In addition to the body's iron stores, the production of the regulatory hormone is also affected by erythropoiesis, hypoxia and inflammatory processes. Abnormal regulation can lead to serious illness through iron deficiency or iron stress. Regarding the processes influencing the formation of hepcidin, our knowledge has significantly increased and the aim of our paper is to present them.

Keywords: hepcidin, ferroportin

(Beérkezett: 2020. december 17.; elfogadva: 2021. március 9.)

\section{Rövidítések}

HAMP gén - hepcidin gén; IRIDA - iron refracter iron deficient anemia; MT2 - matriptáz; RGM - repulsive guidance molecule; HJV - hemojuvelin

A vas a külső elektronhéján elhelyezkedő elektronokat kis energiaközlés hatására le tudja adni, illetve vissza tudja venni - vagyis kiválóan alkalmas oxidációs/redukciós folyamatok katalizálására (1. ábra).

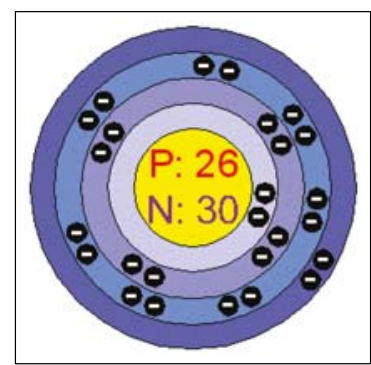

1. ábra. A vasatom sematikus szerkezete

\footnotetext{
@ Levelezési cím: Dr. Egyed Miklós, Somogy Megyei Kaposi Mór Oktató Kórház, H-7400 Kaposvár, Tallián Gyula utca 20-32.; E-mail: dregyedmiklos@yahoo.com; Tel.: +36-30-9021-067; Fax: +36-82-510-076
} 


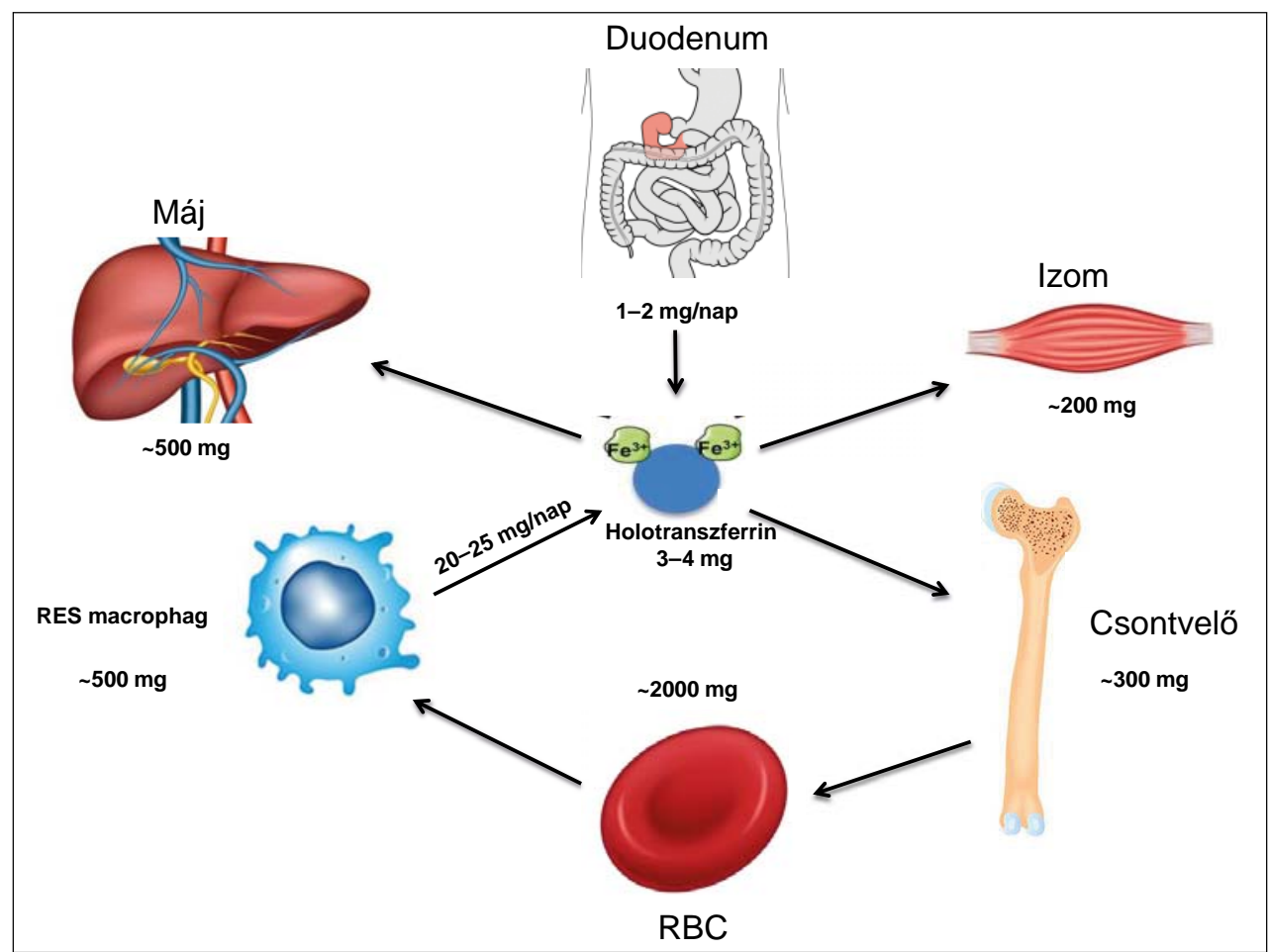

2. ábra. A vas eloszlása a humán szervezetben

A vas felhasználását szolubilitási és toxicitási problémák nehezítik, a szabaddá váló vas erősen mérgező. Szállítása szinte kizárólagosan fehérjékhez kötve történik. Biológiai membránokon való átjutása általában speciális „kapufehérjét”, valamint oxidációs-redukciós folyamatot, azaz elektroncserét igényel, ez utóbbit gyakran a réz biztosítja $[1,2]$.

Egy $70 \mathrm{~kg}$ tömegű felnőtt ember $50 \mathrm{mg} / \mathrm{ttkg}$ vasat tartalmaz, vagyis összesen közel 3500 mg-ot. A teljes vastartalom 2/3-a a keringő vérben található (egy gramm vörösvérsejt $1 \mathrm{mg}$ vasat tartalmaz, így a fenti elképzelt minta 5 liternyi vérében $2000 \mathrm{mg}$ ). A májban lévő stabil vasraktár egyénenként váltakozóan kb. 500 mg, az izomzat 200 mg, a csontvelö $300 \mathrm{mg}$, a RES-rendszer (a lebomlott elöregedett vvs-ből származó) 500 mg vasat tartalmaz (2. ábra).
A napi vasforgalom $20-25 \mathrm{mg}$, amelynek több mint $60 \%$-a az erythropoiesis részére szükséges, a maradék 30-40\% az újraképződő sejtek oxigénellátását és energianyerését teszi lehetővé. Testünk sejtjei a vasszükségletüket a sejtmembránhoz kötött transferrin receptor/holotranszferrin komplex által, egy ún. „receptormediálta endocytosis” útján biztosítják, és speciális módon szabályozzák. A celluláris vasanyagcsere és annak szabályozása nem témája a jelen publikációnak.

A napi $20-25 \mathrm{mg}$ vasforgalomnak a duodenális enterocyta által felszívott $1 \mathrm{mg}$ (menstruáló nőkben $2 \mathrm{mg}$ ) alig 5\%-át biztosítja, a döntő hányad a RES macrophagokból, esetenként a májban lévő vasraktárból jut a vérbe. A boholysejt véráram felőli oldalán (basolateralis felszín), a tároló májsejteken és a RES macrophagokon egy erre a célra elkülönült ún. „kapufehérje” (ferroportin) teszi le=

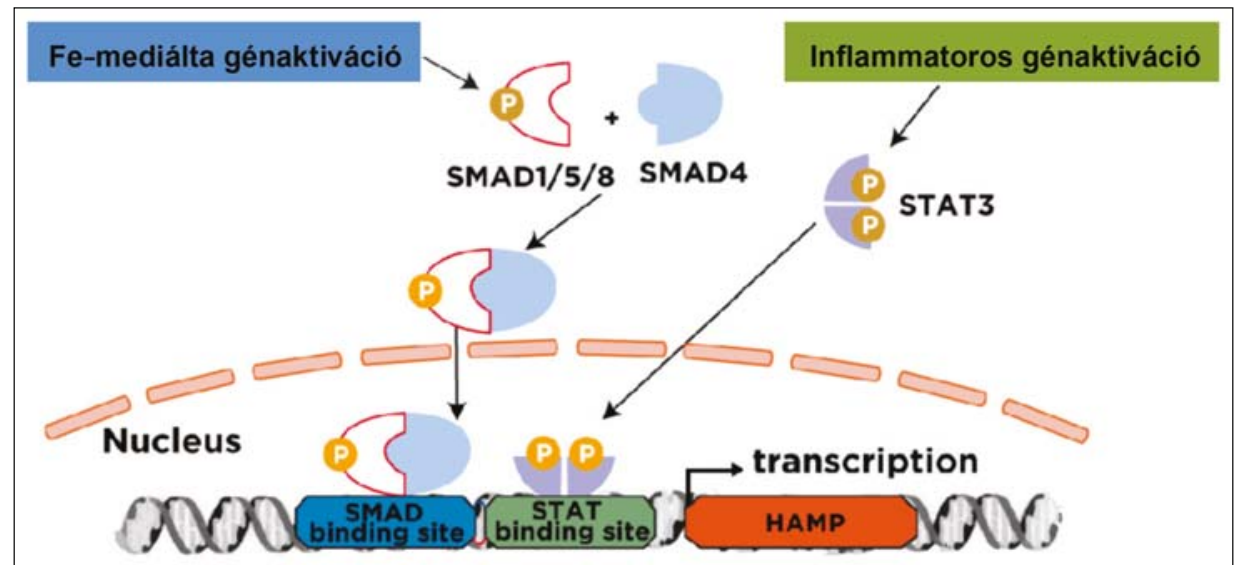

3. ábra. Hepcidin génszerkezete és a gént aktiváló folyamatok 
hetővé a vas véráramba való bejutását. A vasanyagcsere szabályozása, a vasnak a vérbe való belépése a fenti három lehetséges vasdonorból, lényegében a ferroportin szabályozásán keresztül valósul meg [1-5]. A szabályozó hormon a hepcidin, amelyet a májsejtek termelnek [6]. A hepcidint először antimicrobialis peptidként azonosították [6], génje elnevezése is ezt tükrözi. A HAMP gén (human antimicrobial peptid), amely a hepcidint kódolja a 19. kromoszóma q 13.1. lokuszán helyezkedik el. A HAMP gén promoter szakaszán expressziót szabályozó STAT és SMAD válaszelemeket igazoltak (3. ábra).

A hepcidin 84 aminosavból álló preprohormonként keletkezik, amelyből 60 aminosavból álló prohormonon át alakul ki a 25 aminosavból álló hormonná, amely 4 diszulfidhidat tartalmaz. A hepcidinnek a vizeletben 20 és 22 aminosavból álló metabolitjai is léteznek. Az $N$-terminalis aminosavak deléciója funkcióvesztést okoz.

Mai ismereteink szerint a hepcidin a vasanyagcsere szinte minden eltérésében meghatározó szereppel bír, ezért fontos, hogy a képzést szabályozó folyamatokat megismerjük. A hepcidinexpressziót befolyásoló tényezők két csoportra oszthatók: vasmediálta (I.) és vasmentes szabályozókra (II.) - amelyek között az erythropoiesis (II.1), a hypoxia (II.2) és az inflammatoros folyamatok (II.3) játszanak fontos szerepet [7, 8].

\section{A hepcidin vas által befolyásolt expressziója}

Az nyilvánvaló, hogy a vasnak (szabályozott) a hepcidin(szabályozó) expressziójában fontos szerepe kell legyen. Jelenlegi ismereteink szerint egy meglehetősen bonyolult rendszeren a transzferrinhez kötött vas és a macrophag/ hepatocyta interakción, egy membránreceptor/jelátviteli rendszeren keresztül valósul meg. A szabályozásban 8 különböző fehérje vesz részt: hemojuvelin (HJV), herediter hemochromatosis fehérje (HFE), transzferrin, transferrinreceptor 2 (TfR2), bone morphogenic protein 6 (BMP6), BMP-receptor, matriptase-2, neogenin. A következőkben ezen faktorok fontosabb jellemzőit, majd feltételezett müködésüket kívánom bemutatni [2-8].

\section{I.a. Hemojuvelin (HJV)}

A HJV, vagy „repulsive guidance molecule C” (RGMc) vagy hemochromatosis type 2 protein (HFE2). A hemojuvelin a „repulsive guidance” fehérjecsalád tagja, amelyek elsősorban az idegsejtek regenerációiban vesznek részt (RGMa és RGMb), míg a hemojuvelin membránhoz kötött formájában a BMP-receptor stabilizációjában játszik fontos szerepet. Hiányában jelentősen lecsökken a BMP/ SMAD complex által kiváltott hepcidinexpresszió. A HFE2 gén kódolja, amely 4 exont tartalmaz és az RNSérés (splicing) során 3 alternatív mRNS is létrejön. Expressziója legmagasabb a vázizomzatban és a szívben, a transzkripcióját az izomszövet differenciációja szabályozza. Az RGMc molekula a szintézisét követően jelentős át- alakuláson megy át: 2 solubilis egyláncú forma mellett 2 membránkötött egyláncú és egy kétláncú is kialakul. A BMP-2 az egyláncú solubilis és membránkötött formákhoz tud kötődni. A (D172E and G320V) mutáns hemojuvelin BMP-2 kötőképessége csökkent a (G99V) formáé megszűnt.

Jelenleg 43 autoszóm recesszív öröklésmenetü mutációja ismert, és ezek okozzák a „juvenilis hemochromatosis” esetek döntő hányadát (a maradék esetekben maga a hepcidin gén mutált). Ezen esetekben a vizeletben jelentősen lecsökken, vagy kimutathatatlan az ún. „urinary hepcidin”, és megnő az abszorbeált vas mennyisége [9-12].

A neogenin, amely a hepatocyta membránreceptor komplex fontos eleme a kétláncú membránkötött vad típusú hemojuvelinhez és a (G92V) mutánshoz tud kötődni $[11,12]$.

\section{I.b. Herediter hemochromatosis fehérje (HFE)}

A HFE egy membránprotein, szerkezete nagymértékben hasonlít az MHC-I molekulákhoz [13]. Beta-2-microglobulinnal kapcsolódik. Génje emberben a 6-os kromoszóma rövid karján lokalizálódik (6p 22.2). A HFE-gén 7 exont tartalmaz, a fehérje 343 aminosavból áll; rövid intracelluláris részből, transzmembrán doménből, immunglobulin molekulaszerü transzferrinkötő régióját egy signal peptid egészíti ki (4. ábra).

A HFE magas szinten expresszálódik a gyomor epitheliális sejteken, a vékonybél-enterocytákon, a szöveti macrophagokon, a placenta-syncytiotrophoblastokon, a vérmonocytákon és -granulocytákon [14]. A transferrin receptorral való kölcsönhatással szabályozza a hepcidingén-expressziót. A HFE-gén több mint 40 mutációját ismerjük, közülük a fehérje 282 cystein/tirosin aminosavcserét okozó homozygota mutációja okozza a hemochromatosis esetek 90\%-át. Az 5-6. évtizedre kialakuló súlyos/ letális vasterhelés a károsodott hepcidinexpresszió/ hepcidinhiány miatt alakul ki. Csak kaukázusi populációban fordul elő.A heterozygota-mutációk, a H63/D-mutáció homo- és heterozygota formái, illetve az ún. compound

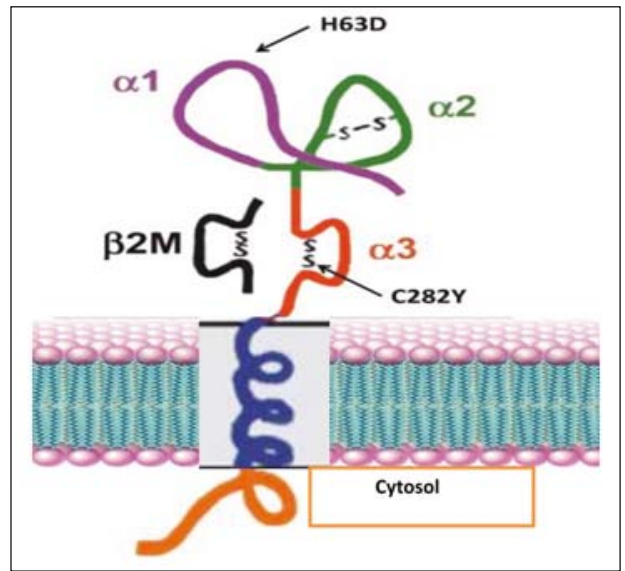

4. ábra. HFE molekula szerkezete a fontosabb mutációk megjelölésével 
heterozygota formák nem vezetnek súlyosabb vasterheléshez, klinikai jelentőségük csekély [1-4].

\section{I.c. Transferrin}

A transferrin $76 \mathrm{kDa}$ glycoprotein a legfontosabb vérben lévő vastranszporter. $2 \mathrm{Fe}(\mathrm{III})$ kötőpontja képes a vas megkötésére [1-4, 15]. Egy időpontban 3-4 mg kötött vasat szállít, és a napi 24-25 mg-os vasforgalmat 3 órás turnoverrel bonyolítja le. A vér 7,4 pH mellett megköti a vasraktárakból (RES macrophag, hepatocyta) és a duodenalis enterocytából érkező vasat, speciális transferrinreceptorokhoz kötődve, a complex internalizációja (receptormediált endocytosis) következik be. Az intracelluláris savas $(\mathrm{pH} 5,0)$ mellett a vasat leadja, ezt követően a sejtfelszínen leválik a receptorról, és kb. 3 óra múlva a folyamat ismétlődik [16].

\section{I.d. Transferrin receptor 2. (TfR2) [17]}

A TfR1 receptor testünk szinte minden sejtjének vasellátásában meghatározó szerepet játszik, a TfR2-nek a transferrinhez kötött vas sejtekbe juttatása (fóleg hepatocyta) mellett fontos szerepe van a májsejtek hepcidinképzésében és a vörösvérsejtek érésében.

A Lys-172 mutációja, amely az ún. iniciációs kodont érinti, lehetetlenné teszi az mRNS transzlációját, és ezáltal a herediter hemochromatosis III típusát okozza, amelynek klinikai megjelenése a HFE-mutáns képpel megegyezik (hiszen egy komplexet alkotnak) [1, 18].

\section{I.e. Bone morphogenic protein (BMP)}

A BMP ligandok a transzformáló growth factor- $\beta$ (TGF $\beta$ ) családba tartoznak, emberben több mint 20 tagjuk ismert [19], kódoló génjük a 6-os kromoszóma 6p12.1 lokuszán található. Lévén az ismert receptoraikat jelentősen meghaladó nagyszámú TGF $\beta$ ligand, nehezen érthető, hogyan fejthetnek ki ligandspecifikus hatást. Feltételezhetően a ligand-receptor kapcsolatát számos járulékos fehérje és SMAD transcriptiós faktorok segítik. A magzati életben betöltött sejtdifferenciáló hatásuk mellett központi szerepük van a vasanyagcserében. Amíg in vitro májsejtkultúrákban a BMP-2, -4, -5, -6, -7 és -9 is jelentősen fokozni tudta a hepcidinexpressziót, addig in vivo a BMP-6 kulcsszerepe bizonyítható [20]. A BMP-6 az ún. nonparenchymalis májsejtekben - döntően a sinusoidális endothelsejtekben képződik. Expressziójában nem a szérum vasszintek, hanem elsősorban a máj vastartalma játszik szerepet (a máj vasraktárállapotának megfelelően befolyásolja a májsejtek hepcidinexpresszióját) [21]. A hepcidinreguláció a SMAD jelátviteli úton, a BMP-receptor/Hemojuvelin co-receptor modulációjával történik.

\section{I.f. Bone Morphogenetic Protein Receptor/ $B M P$ receptorok}

A transzformáló növekedési factor (TGF-beta) családba tartozó két serine/threonine kinase receptorcsoport (I-es típusú receptorok: Alk1, Alk2, Alk3 és Alk6: II-es típusú receptorok: BMPR2, ActRIIa és ActRIIb), amelyek jelátvitele Smad-függő és Smad-független úton valósul meg. Rendkívül változó funkcióit ismerjük, az embriogenezis, a hematopoiesis, a csont- és porcszövetek, idegsejtek képzéséig. A BMP ligandoknak a receptorokhoz való kötődésére a II-es típusú receptor phosphorylálódik, és aktiválja az I-es receptort, amely megindítja a SMAD1, -5 és -8 aktivációját, és a complex SMAD4 kötése után bejut a sejtmagba, ahol génaktivációt indít el (pl. hepcidin). A BMP receptorgének mutációja pulmonalis venoocclusiv betegséget és pulmonalis hypertoniát okozhat [3, 22-24].

\section{I.g. MT2, Matriptase-2/TMPRSS6}

A matriptase egy transzmembrán serin protease (5. ábra). Az $N$ terminálisát egy rövid intracelluláris farok, egy

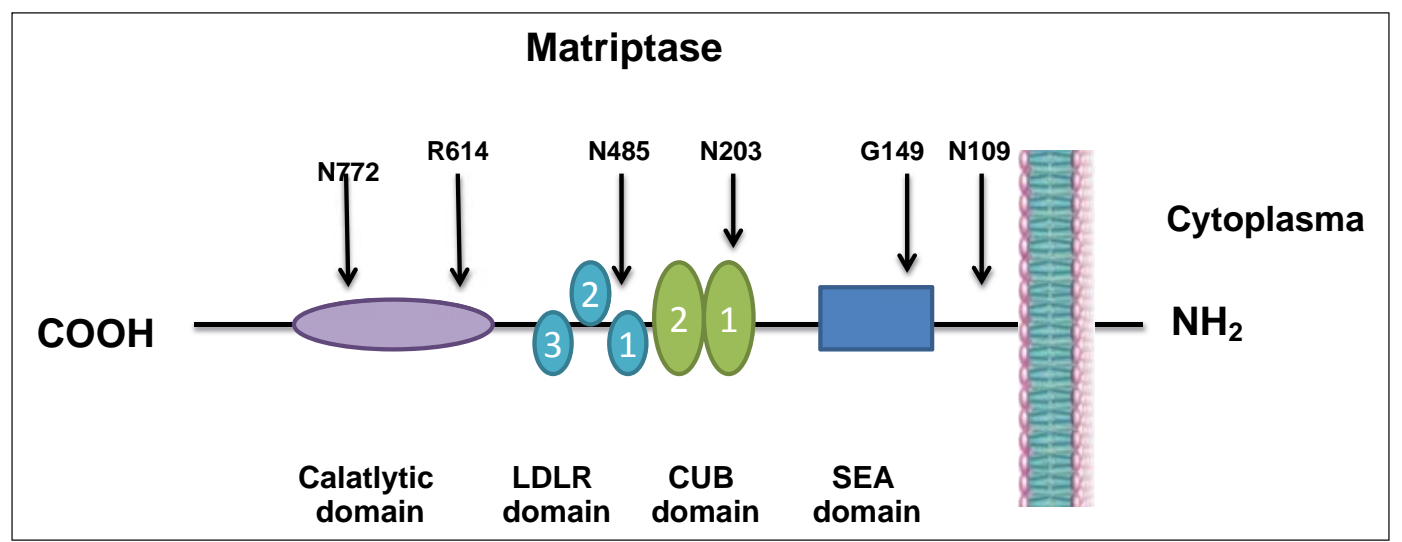

5. ábra. A matriptase szerkezete. Az $N$ terminálisát egy rövid intracelluláris farokrész, egy transmembran domén és egy extracelluláris rész alkotja. Ez utóbbi 7 doménból áll: egy SEA (sea urchin sperm protein, enteropeptidase és a grin), 2 CUB (complement factor C1s/ C1r, urchin embryonic growth factor és BMP), 3 LDLR (low-density lipoprotein receptor repeat) és a C terminus pedig egy tripszinszerü proteázból áll. A felső számok és nyilak a gyakori mutáció helyeit mutatják. 
transzmembrán domén és egy extracelluláris rész alkotja. Ez utóbbi 7 doménból áll: egy SEA (sea urchin sperm protein, enteropeptidase, agrin), 2 CUB (complement factor $\mathrm{C} 1 \mathrm{~s} / \mathrm{C} 1 \mathrm{r}$, urchin embryonic growth factor és BMP), 3 LDLR (low-density lipoprotein receptor repeat) és a C terminusát pedig egy tripszinszerű proteáz alkotja.

A májsejtek magas, a herék, mellékvesék, vesék és uterus alacsony szinteken expresszálják.

A TMPRSS6 gén expresszióját a HIF-1 alfa és a plazmavasszint gyors csökkenése fokozza.

A matriptase vasanyagcserében ismert legfontosabb hatása, a BMP receptorhoz kötött hemojuvelin leválasztása a sejtmembránról, ezáltal a BMP jelátvitel gátlásával a hepcidin képzését súlyosan csökkenti és vasterhelést okoz [3, 25-27]. Neogeninnel való kapcsolódása fokozza a BMP receptorhoz kötött hemojuvelin felszabadítását. A molekula nonsense, missense, splicing junction és frameshift mutációi pedig a hepcidin túlzott képzéséhez és IRIDA (iron refracter iron-deficient anemia) kialakulásához vezetnek [28], amely nagyon ritka betegség. Autosom recesszív öröklésmenettel, hypochrom-microcytaer vvs morfológiával, alacsony Tf-szaturációval és magas hepcidinszinttel jellemezhető. Általában csecsemőkorban, ritkábban fiatal felnőttkorban jelentkezik. A magas hepcidin által okozott ferroportin müködészavar miatt az enterális vaspótlás elégtelen, a parenterális forma eredményes lehet.

\section{I.h. Neogenin}

A neogenin az immunoglobulin családba tartozó multifunkciós transzmembrán receptor, fontos szerepe van a netrin és repulsive guidance fehérjék (RGM) jelátvitelében, ezáltal a szöveti morfogenezisben, különösképpen az idegsejtek differenciálódásában. Vasanyagcserében betöltött fontos szerepét a HJV-expresszió szabályozásával és a HJV molekula stabilizálásával, ezáltal a BMP jelátvitel befolyásolásával magyarázzuk. Mutációi a hepcidinexpresszió csökkenéséhez és vasterheléshez vezetnek $[3,11,12]$.

\section{A hepcidinexpresszió feltételezett vas általi szabályozása}

A szervezet vastartalma által szabályozott hepcidinexpresszió a BMP jelátviteli úton zajlik, amelynek épsége felelős a fiziológiás müködésért, és amelyet a vas két formában/úton befolyásolhat. Mai ismereteink egy meglehetősen összetett és müködésében még nem minden részletében ismert (gyakran csak egérkísérletekben igazolt) BMP-R-aktiváló komplexet igazolnak. A plazma aktuális vastartalmának emelkedése (amelyet a Tf-szaturációval HoloTf - jellemzünk) a hepatocyta felszínén a TfR1-HFE komplex szétesését és a HFE-TfR2 komplex képzését segíti elő. A HFE-TfR2 HJV-interakció ún. „vasérzékenyítő komplexet" hoz létre [29, 30], és a BMP-R jelátvitel akti- válásával a hepcidin expresszióját fokozza. A májsejtek vasraktárai az ún. „nonparenchymal” sejtekből (leginkább sinusoidalis endothelsejtek) a BMP6 képzésén keresztül fokozzák a hepcidin képzését [31]. Más elképzelés szerint a sinusoidalis endothelsejtekben a „vasérzékenyítő komplex" fokozná a BMP6-, és ezáltal a hepcidinképzés fokozását (6. ábra).

A BMP-receptor müködéséhez feltétlenül szükséges a HJV co-receptor membránkötött forma jelenléte (valószínü, hogy a neogenin és a HFE-TfR2 részvétele is fontos) $[3,11,12]$. A TM2 aktivációja, amely lemetszi a hepatocytamembránról a HJV molekulát [27], mindkét, a vas által befolyásolt BMP-R jelátviteli út blokkolását okozva gátolja a hepcidinexpressziót.

A BMP jelátvitel patológiás eltérései különféle betegségekhez vezethetnek. A BMP/SMAD jelátvitelben érintett gének mutációi hemochromatosis, illetve vasrefrakter vashiányos anemia (IRIDA) kialakulásához vezethetnek [28].

A hepcidinexpresszió csökkenése haemochromatosist okozhat, a ma elfogadott nemzetközi osztályozás szerint a HFE mutációi az I-es, a HJV-mutációk a IIA, a HAMP génmutációk a IIB, a TfR2-mutációk a III-as típust okozzák (a ferroportin mutációi a IV. típusért felelősek) [32].

A BMP6 (mRNS vasszabályozott) hiánya (mutációi) gyors és súlyos vasterheléshez vezetnek, a klinikai kép a II. típusú haemochromatosissal azonos [33]. Az ineffek-

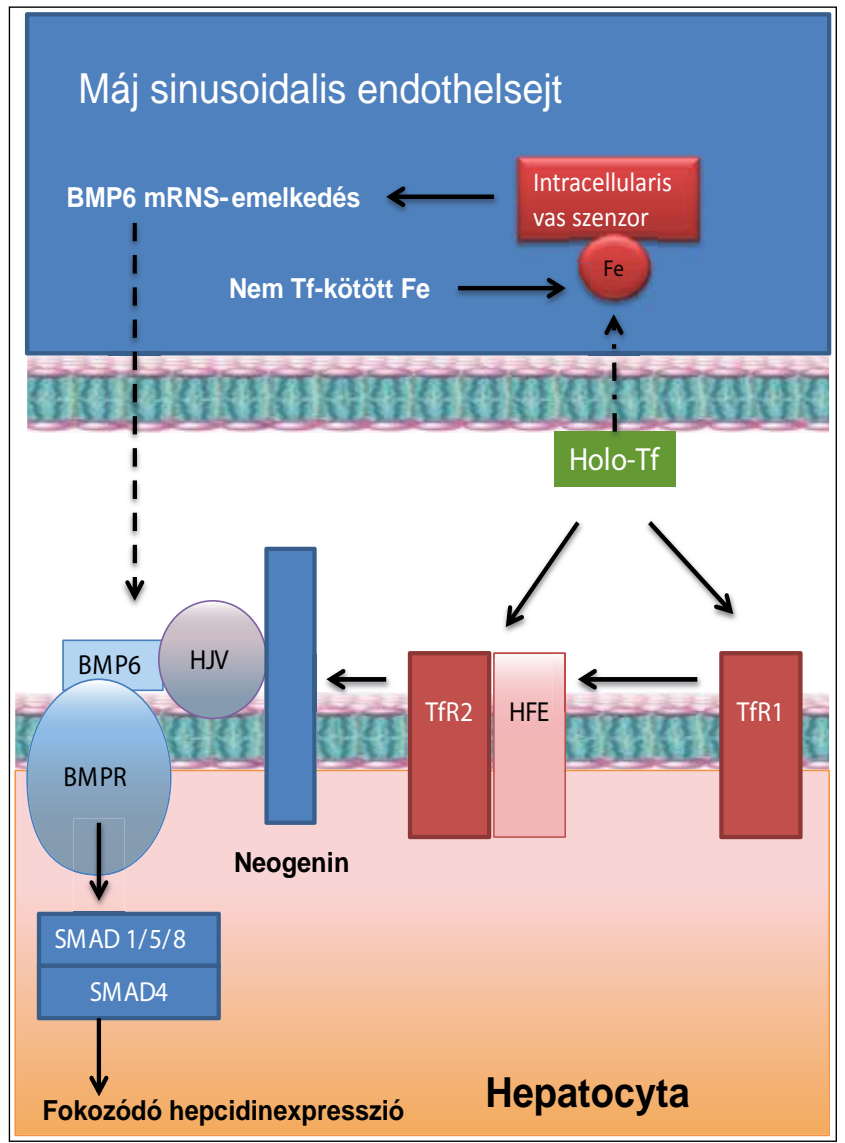

6. ábra. A máj szinuszoidális sejt hepcidinszabályozása 


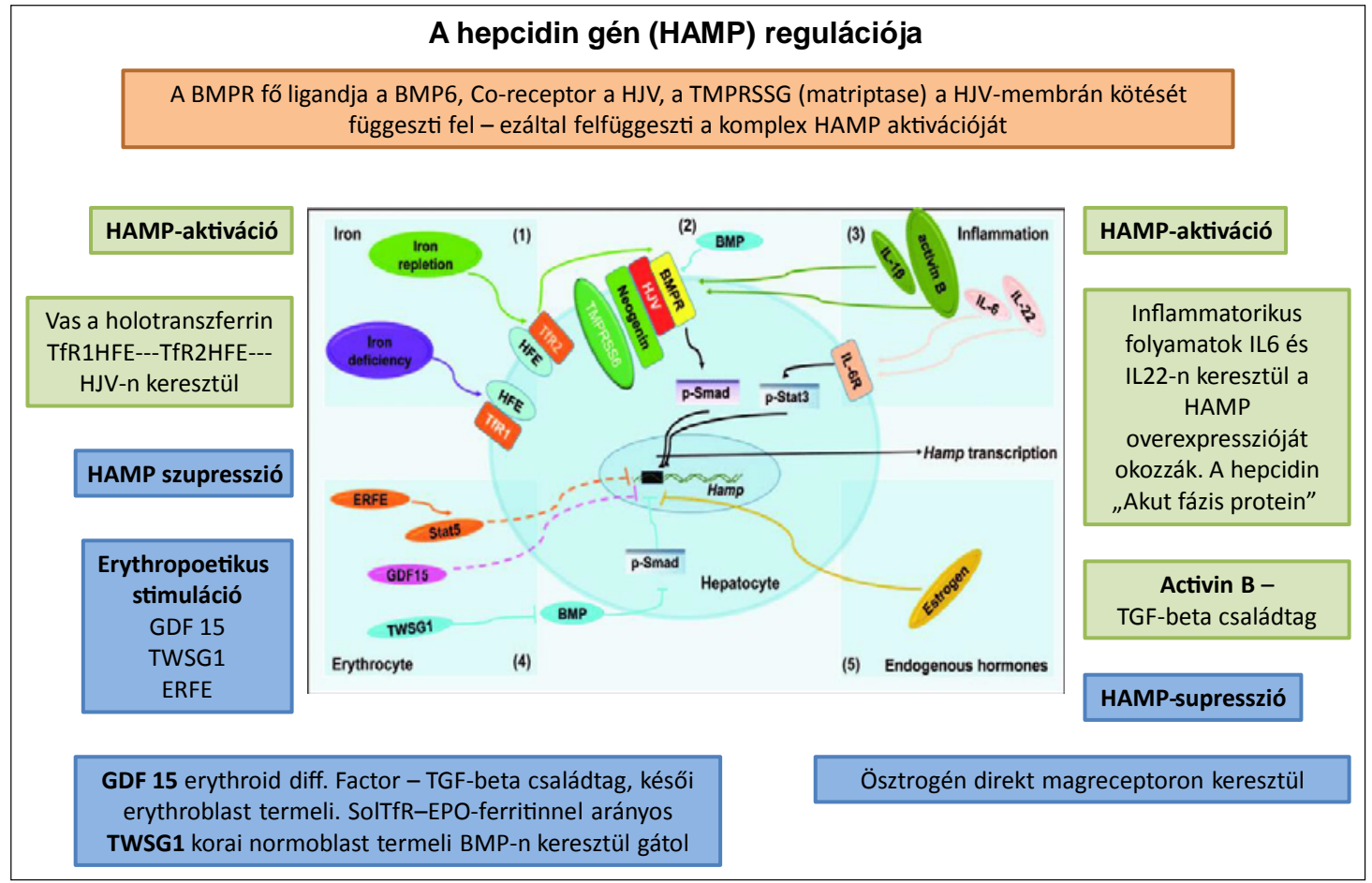

7. ábra. A hepcidin gén (HAMP) szabályozása

tív erythropoiesis során feltételezhetően TWG (twisted gastrulation) [34] és GDF (growth and differentiated factor) [35] hepcidinexpresszió-gátló szerepét ma többen megkérdőjelezik, azonban a klinikumban jól ismert a myelodysplasiákban, elsősorban az MDS-RS esetekben észlelt jelentős és gyorsan kialakuló vasterhelés, amelyet egyesek V. típusú haemochromatosisnak neveznek (7. ábra).

\section{A hepcidin vas által nem befolyásolt expressziója}

Ismereteink szerint az erythropoiesis, a hypoxia és az inflammatorikus folyamatok direkt befolyásolni tudják a hepcidin expresszióját. Természetesen a fokozott vagy csökkent hepcidin a ferroportin útján órák alatt befolyásolja a vasanyagcserét, a vér vastartalmát, amely az elözőekben részletezett módon visszahat a hepcidinképzésre.

\section{II.1. Erythropoiesis}

Lévén, hogy a szervezet vaskészletének közel 2/3-a a vörösvérsejtekben található és ismerve az erythropoiesis igen kifejezett vasigényét, könnyen belátható, hogy fontos szerepe kell legyen a vasanyagcsere szabályozásában. Erythropoietikus stimulusok: anemia, hypoxia, EPOkészítmények alkalmazása csökkentik a hepcidin képzését [3]. A vas duodenális absorptio tanulmányozása során már korán megfigyelték, hogy nagyobb vérzések során még akkor is robbanásszerű vasfelszívás történik, ha egyébként a vasraktárak csordultig töltöttek, vagy akár komoly vasterhelés állapotában van a szervezet (pl. haemochromatosisos beteg oesophagus varixvérzése). Korábban a duodenalis absorptio hátterében egynapi, 2-3 mg-ért felelős „raktár regulátor”, és egy 20-25 mg vasfelszívást is lehetővé tévő, ún. „erythroid regulátort” feltételeztek. Ez utóbbi hatásával magyarázták a nagy vérvesztést követő igen kifejezett vasabsorptiót [1]. Ma ezeket a regulátorokat inkább a hepcidinexpresszió eltérő szintü gátlásával magyarázzuk, bár a BMP-6 leginkább a májsejtek vasraktáráról, az erythroferron pedig az ún. „stress erythropoiesis” vasigényéről jelezvén befolyásolja a hepcidinexpressziót $[3,36]$.

\section{Erythroferron (ERFE)}

Erythropoietikus stimulusok - vérvesztés, hypoxia, EPO-készítmények alkalmazását követően - a hepcidinexpresszió csökkenését igazolták. Ennek hátterében feltételeztek és 2014-ben izoláltak is egy hormont, amelyet erythroferronnak (ERFE) neveztek el [36, 37]. A molekulát emberben a FAM 132B gén kódolja, 354 aminosavból áll, az erythroblastok minden érési stádiumukban termelik. Korábban a humán vázizomsejtekben már kimutatták myonectin, illetve CTRP15 (C1q/TNF-related protein) néven. Korábbi elképzelés szerint az ERFE járulékos sejtek nélkül, a STAT5 jelátviteli út aktivációjával direkt csökkenti a májsejtek hepcidinexpresszióját [3, 38]. Újabb irodalmi adatok szerint a BMP fehérjék megkötése révén a SMAD jelátvitel blokkolása felelős a HAMP gén blokkolásáért [39]. Hatására az ún. stressz erythropoiesis esetén számíthatunk, a normál vérképzésben nincs szerepe. A fokozott erythropoiesis emelkedett vasigényét az ERFE a vasdonátor sejtekből való vasfelszabadulás segítségével 
éri el. Az ERFE emelkedett értékeit igazolták immunoassay méréssel vérvesztések és EPO alkalmazását követően [38]. Béta-thalassaemiában nagyon magas, vértranszfúzió után csökkenő szintjeit igazolták egérben [40].

\section{II.2. Hурохіа}

A szövetek, elsősorban a vese hypoxiája számos módon befolyásolhatja a hepcidinképzést és ezáltal a vasanyagcserét.

Egyik elképzelés szerint a szöveti hypoxia a szervezet vasháztartásától függetlenül direkt gátolni tudja a májsejtek hepcidinképzését [3], ezért az ineffektív erythropoiesis talaján kialakuló anemia okozta hypoxia szerepet játszhat a vasanyagcsere szabályozásában (vasterhelést okozva) $[34,35]$.

Más feltételezés szerint a szöveti hypoxia az erythropoietinképzésen keresztül fokozza az erythropoiesist és ezáltal befolyásolja a vasanyagcserét [41].

Hypoxia-inducible faktorok (HIF) olyan transzkripciós faktorok, amelyek a szöveti hypoxiát érzékelve befolyásolják az erythropoietin képzését (7. ábra). A HIF-1a és a HIF-2a normoxiás környezetben hydroxylációt követően (HIF prolylhydroxylase, PHD) a Von Hippel-Lindau-fehérjéhez (VHL) kötődik, majd a complex ubiquitinációt követően proteoszomálisan degradálódik. Hypoxiás környezetben a HIF-1 $\beta$-val kapcsolódva a sejtmagba kerül, ahol az erythropoietin, a glycolysis és az angiogenezisben fontos gének expresszióját segítik elő. A hydroxyláció gátlása kismolekulájú szerekkel (roxadustat, vadadustat, daprodustat és molidustat) az anemia, fóként a vesebetegek anemiájának kezelésében látszik ígéretesnek [42]. A VHL, PHD2, HIF-1 $\alpha$, HIF-2a gének mutációi familiáris erythrocytosist okoznak. A Chuvash-polycy- thaemia a VHL gének homozygota missens mutációja miatt alakul ki. E kórképekben normoxiás környezetben a sejtek hypoxiát érzékelnek, és fokozott erythropoietinképzést indikálnak, amely erythrocytosishoz vezet. Általában fokozott érrendszer eredetű tumorképződésre hajlamosítanak.

\section{I.3. Inflammatorikus folyamatok}

A vas alapvető fontosságú a kórokozó baktériumok számára, mert hiányában nem képesek energiát nyerni, szaporodni. Az infectio által sújtott humán szervezet fontos védekezési lehetősége ezért vaskészleteinek elrejtése. Az inflammatorikus reakció során gyulladásos cytokinek IL6 [43] IL1 $\beta$ [44], IL 22 [45], IL1 [44] - képződnek, amelyek fokozni tudják a hepcidin expresszióját [3, 43, 46], amely ferroportin degradálásával órák alatt hypoferreaemiát okoz.

Leginkább ismert az IL6 hatása, amely a legtöbb extracelluláris pathogén, bizonyos malignus folyamatok és autoimmun kórképek által keltett jelet a JAK-STAT 3 jelátviteli úton a HAMP gén promoterének aktivációjával éri el $[3,43]$. A hepcidin gén mellett számos egyéb fehérje génjét is aktiválni tudja (CRP, ferritin, fibrinogen, VIII-as faktor-antihemophyliás globulin), ezeket akut fázis fehérjéknek hívjuk. Mivel vérszintjük a hepcidinnel párhuzamosan alakul, így a mindennapi gyakorlatban például a CRP mérése elegendő a hepcidin helyett.

Az IL22 szerepe kevésbé látszik fontosnak az inflammatorikus folyamatokban [45].

IL1 $\beta$ egerekben bizonyos bakteriális fertőzésekben a BMP-R-SMAD út aktivációjával okozott hepcidinexpreszsziót $[3,44]$. Emberben, IBD-ben merült fel az IL1 $\beta$ hepcidin indukciós szerepe.

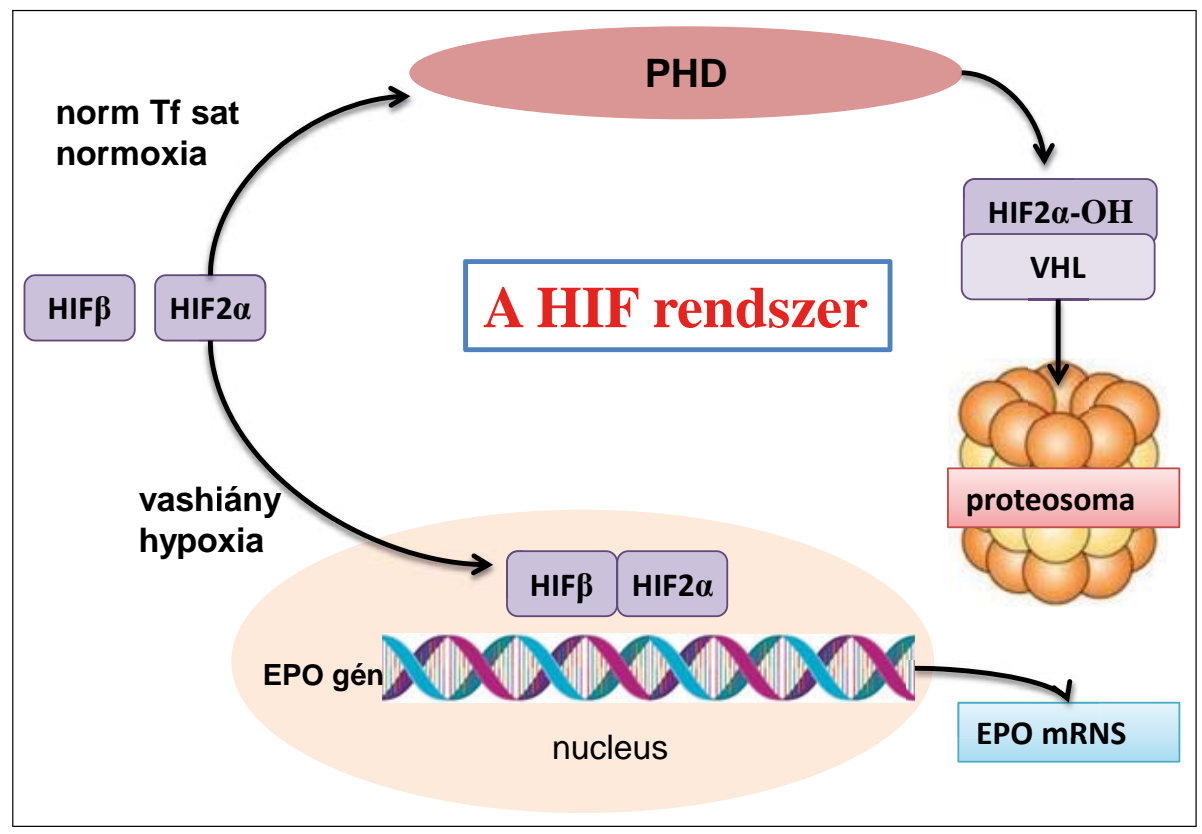

8. ábra. A HIF rendszer 
A vashiány és az inflammatorikus folyamatok hepcidinexpresszióra kifejtett hatásának sorrendjében, a vashiány bizonyult elsődlegesnek [3, 46].

Nyilatkozat: A kézirat más folyóiratban korábban nem jelent meg és máshova beküldésre nem került. A levelező szerző elolvasta a Hematológia-Transzfuziológia szerzői útmutatóját.

Érdekeltségek: A szerzőnek a közleményhez kapcsolódó közvetlen érdekeltségei nincsenek.

Anyagi támogatás: A szerző a közlemény megírásához anyagi támogatásban nem részesült.

\section{Irodalom}

[1] Egyed M. Iron metabolism and its disorders. [A vasanyagcsere és betegségei.] Semmelweis Kiadó, Budapest, 2007

[2] Ganz T. Systemic iron homeostasis. Physiological Reviews 2013; 93: 1721-1741.

[3] Roth MP, Meynard D, Coppin H. Regulators of hepcidin expression. Vitamins and Hormones 2019; 110: 101-129.

[4] Girelli D, Nemeth E, Swinkels DW. Hepcidin in the diagnosis of iron disorders. Blood 2016; 127: 2809-2813.

[5] Nemeth E, Tuttle MS, Powelson J, et al. Hepcidin regulates cellular iron efflux by binding to ferroportin and inducing its internalization. Science 2004; 306: 2090-2093.

[6] Park CH, Valore EV, Waring AJ, Ganz T. Hepcidin, a urinary antimicrobial peptide synthesized in the liver. J Biol Chem 2001; 276: 7806-7810.

[7] Zhao N, Zhang AS, Enns CA. Iron regulation by hepcidin. J Clin Invest 2013; 123: 2337-2343.

[8] Nicolas G, Chauvet C, Viatte L, et al. The gene encoding the iron regulatory peptide hepcidin is regulated by anemia, hypoxia, and inflammation. J Clin Invest 110: 1037-1044.

[9] Niederkofler V, Salie R, Arber S. Hemojuvelin is essential for dietary iron sensing, and its mutation leads to severe iron overload. J Clin Invest 2005; 115: 2180-2186.

[10] Nili M, Shinde U, Rotwein P. Soluble repulsive guidance molecule $\mathrm{c} /$ hemojuvelin is a broad spectrum bone morphogenetic protein (BMP) antagonist and inhibits both BMP2- and BMP6-mediated signaling and gene expression. J Biol Chem 2010; 285: 24783-24792.

[11] Zhang AS, Yang F, Meyer K, et al. Neogenin-mediated hemojuvelin shedding occurs after hemojuvelin traffics to the plasma membrane. J Biol Chem 2008; 283: 17494-17502.

[12] Healey EG, Bishop B, Elegheert J, et al. Repulsive guidance molecule is a structural bridge between neogenin and bone morphogenetic protein. Nat Struct Mol Biol 2015; 22: 458-465.

[13] Feder JN, Gnirke A, Thomas W, et al. A novel MHC class I-like gene is mutated in patients with hereditary haemochromatosis. Nature Genetics 1996; 13: 399-408.

[14] Parkkila S, Parkkila AK, Waheed A, et al. Cell surface expression of HFE protein in epithelial cells, macrophages, and monocytes. Haematologica 2000; 85: 340-345.

[15] Baker EN, Lindley PF. New perspectives on the structure and function of transferrins. Journal of Inorganic Biochemistry 1992; 47: $147-160$.

[16] Kawabata H. Transferrin and transferrin receptors update. Free Radical Biology \& Medicine. 2019; 133: 46-54.

[17] Kawabata H, Yang R, Hirama T, et al. Molecular cloning of transferrin receptor 2. A new member of the transferrin receptor-like family. J Biol Chem 1999; 274: 20826-20832.
[18] Roetto A, Totaro A, Piperno A, et al. New mutations inactivating transferrin receptor 2 in hemochromatosis type 3. Blood 2001; 97: 2555-2560.

[19] Parrow NL, Fleming RE. Bone morphogenetic proteins as regulators of iron metabolism. Annu Rev Nutr 2014; 34: 77-94.

[20] Andriopoulos B Jr, Corradini E, Xia Y, et al. BMP6 is a key endogenous regulator of hepcidin expression and iron metabolism. Nat Genet 2009; 41: 482-487.

[21] Corradini E, Meynard D, Wu Q et al. Serum and liver iron differently regulate the bone morphogenetic protein 6 (BMP6)-SMAD signaling pathway in mice. Hepatology 2011; 54: 273-284.

[22] Mayeur C, Leyton PA, Kolodziej SA, et al. BMP type II receptors have redundant roles in the regulation of hepatic hepcidin gene expression and iron metabolism. Blood 2014; 124: 21162123.

[23] Mayeur C, Lohmeyer LK, Leyton P, et al. The type I BMP receptor Alk3 is required for the induction of hepatic hepcidin gene expression by interleukin-6. Blood 2014; 123: 2261-2268.

[24] Nohe A, Hassel S, Ehrlich M, et al. The mode of bone morphogenetic protein (BMP) receptor oligomerization determines different BMP-2 signaling pathways. J Biol Chem 2002; 277: 53305338.

[25] Folgueras AR, de Lara FM, Pendas AM, et al. Membrane-bound serine protease matriptase-2 (Tmprss6) is an essential regulator of iron homeostasis Blood 2008; 112: 2539-2545.

[26] Silvestri L, Guillem F, Pagani A, et al. Molecular mechanisms of the defective hepcidin inhibition in TMPRSS6 mutations associated with iron-refractory iron deficiency anemia. Blood 2009; 8: 8.

[27] Silvestri L, Pagani A, Nai A, et al. The serine protease matriptase-2 (TMPRSS6) inhibits hepcidin activation by cleaving membrane hemojuvelin. Cell Metab 2008; 8: 502-511.

[28] Finberg KE, Heeney MM, Campagna DR, et al. Mutations in TMPRSS6 cause iron-refractory iron deficiency anemia (IRIDA). Nat Genet 2008; 40: 569-571.

[29] D'Alessio F, Hentze MW, Muckenthaler MU. The hemochromatosis proteins HFE, TfR2, and HJV form a membrane-associated protein complex for hepcidin regulation. J Hepatol 2012; 57: $1052-1060$.

[30] Goswami T, Andrews NC. Hereditary hemochromatosis protein, HFE, interaction with transferrin receptor 2 suggests a molecular mechanism for mammalian iron sensing. J Biol Chem 2006; 281 : 28494-28498.

[31] Enns CA, Ahmed R, Wang J, et al. Increased iron loading induces Bmp6 expression in the non-parenchymal cells of the liver independent of the BMP-signaling pathway. PLoS One 2013; 8: e60534.

[32] Camaschella C. Understanding iron homeostasis through genetic analysis of hemochromatosis and related disorders. Blood 2005; (12): 3710-3717.

[33] Meynard D, Kautz L, Darnaud V, Canonne-Hergaux F. Lack of the bone morphogenetic protein BMP6 induces massive iron overload. Nat Genet 2009; 41: 478-481.

[34] Tanno T, Porayette P, Sripichai O, et al. Identification of TWSG1 as a second novel erythroid regulator of hepcidin expression in murine and human cells. Blood 2009; 114: 181-186.

[35] Tanno T, Bhanu NV, Oneal PA, et al. High levels of GDF15 in thalassemia suppress expression of the iron regulatory protein hepcidin. Nat Med 2017; 13: 1096-1101.

[36] Kautz L, Jung G, Valore EV, et al. Identification of erythroferrone as an erythroid regulator of iron metabolism. Nat Genet 2014; 46: 678-684.

[37] Coffey R, Ganz T. Erythroferrone: An erythroid regulator of hepcidin and iron metabolism. HemaSphere 2018; 2(2): e35. DOI: $10.1097 /$ HS9.0000000000000035.

[38] Ganz T, Jung G, Naeim A, et al. Immunoassay for human serum erythroferron. Blood 2017; 130: 1243-1246. 
[39] Katsarou A, Pantopoulos K. Basics and principles of cellular and systemic iron homeostasis. Molecular Aspects of Medicine 2020; 75: 100866.

[40] Kautz L, Jung G, Du X, et al. Erythroferrone contributes to hepcidin suppression and iron overload in a mouse model of $\beta$-thalassemia. Blood 2015; 126: 2031-2037.

[41] Liu Q, Davidoff O, Niss K, Haase VH. Hypoxia-inducible factor regulates hepcidin via erythropoietin-induced erythropoiesis. J Clin Invest 2015; 122: 4635-4644.

[42] Gupta N, Wish JB. Hypoxia-inducible factor prolyl hydroxylase inhibitors: a potential new treatment for anemia in patients with CKD. American Journal of Kidney Diseases 2017; 69: 815-826.
[43] Wang CY, Babitt JL. Hepcidin regulation in the anemia of inflammation. Curr Opin Hematol 2016; 23: 189-197.

[44] Sangkhae V, Nemeth E. To induce or not to induce: the fight over hepcidin regulation. Hematologica 2019; 104: 1093-1095.

[45] Wallace DF, Subramaniam VN. Analysis of IL-22 contribution to hepcidin induction and hypoferremia during the response to LPS in vivo. Int Immunol 2015; 27: 281-287.

[46] Shanmugam NK, Chen K, Cherayil BJ. Commensal bacteria-induced interleukin $1 \beta$ (IL-1 $\beta$ ) secreted by macrophages up-regulates hepcidin expression in hepatocytes by activating the bone morphogenetic protein signaling pathway. J Biol Chem 2015; 290: 30637-30647.

A cikk a Creative Commons Attribution 4.0 International License (https://creativecommons.org/licenses/by/4.0/) feltételei szerint publikált Open Access közlemény, melynek szellemében a cikk bármilyen médiumban szabadon felhasználható, megosztható és újraközölhető, feltéve, hogy az eredeti szerző és a közlés helye, illetve a CC License linkje és az esetlegesen végrehajtott módosítások feltüntetésre kerülnek. (SID_1) 